\title{
TINJAUAN HUKUM ISLAM TERHADAP OVERMACHT DALAM PERJANJIAN PEMBORONGAN PEMBUATAN IRIGASI (STUDI KASUS DI DESA PUNTI KECAMATAN SOROMANDI KABUPATEN BIMA)
}

\author{
Nur Sinta dan Saprudin \\ Institut Agama Islam Negeri (IAIN) Mataram
}

\begin{abstract}
Abstrak
Pembangunan di bidang fisik dewasa ini perkembangannya seiring dengan tuntutan masyarakat, kemajuan ilmu pengetahuan dan teknologi. Pembangunan fisik seperti gedung sekolah, jalan tol, rumah sakit, dan lain-lain adalah obyek dari perjanjian bangunan. Perjanjian bangunan dilihat dari sistem hukum merupakan salah satu komponen dari hukum bangungan (bouhwrect), bangunan disini mempunyai arti luas, yaitu segala sesuatu yang didirikan diatas tanah. Dengan demikian dinamakan hukum bangunan adalah seluruh perangkat peraturan perundang-undangan yang berhubungan dengan bangunan meliputi, pendirian, perawatan, pembongkaran, penyerahan baik bersifat perdata maupun publik. Overmacht/Force majeure dalam hukum perdata positif diatur dalam KUH Perdata pasal 1244 dan 1245, dalam bagian mengenai ganti rugi karena overmacht/force majeure merupakan alasan untuk dibebaskan dari kewajiban membayar ganti rugi.
\end{abstract}

Kata Kunci : Overmacht, perjanjian, pemborongan

A. PENDAHULUAN

Pembangunan adalah usaha menciptakan kemakmuran dan kesejahteraan rakyat. Oleh karena itu, hasil pembangunan harus dinikmati seluruh rakyat sebagai peningkatan kesejahteraan lahir dan bathin secara adil dan makmur. Sebaliknya, berhasilnya pembangunan bergantung partisipasi seluruh rakyat, yang berarti pembangunan harus dilaksanakan seluruh rakyat merata dan segenap lapisan masyarakat.
Secara garis besar, tatanan hukumperdata Indonesia memberikan peluang yang seluas-luasnya bagi masyarakat untuk saling mengadakan perjanjian tentang apa saja yang dianggap perlu bagi tujuannya. Sebagaimana ketentuan pasal 1338 Kitab Undang-Undang Hukum Perdata (KUHP) menyatakan bahwa semua perjanjian dibuat secara sah berlaku sebagaimana undang-undang bagi mereka yang membuatnya. Menyikapi hal tersebut R. Subekti 
menjelaskanbahwakitadiperbolehkan membuat perjanjian yang berupa/ berisi apa saja (atau tentang apa saja) dan perjanjian itu akan mereka yang membuatnya seperti undangundang. Atau dengan perkataan lain, dalam persoalan perjanjian, kita diperbolehkan membuat undangundang bagi kita sendiri. Pasalpasal dari hukum perjanjian hanya berlaku, apabila tau sekedar kita tidak mengadakan aturan-aturan sendiri dalam perjanjian-perjanjian yang kita adakan itu". ${ }^{17}$

Pembangunan Irigasi diatur dalam Peraturan Pemerintah Republik Indonesia Nomor 20, Tahun 2006 tentang Irigasi. Pengertian Irigasi tercantum dalam Pasal 1 butir ke-3, Irigasi adalah usaha penyediaan, pengaturan, dan pembuangan air irigasi untuk menunjak pertanian yang jenisnya meliputi irigasi permukaan, irigasi rawa, irigasi air bawah tanah, irigasi pompa, dan irigasi tambak.

Di negara berkembang Khususnya Indonesia mengalami krisis multi dimensi berkepanjangan masih menitiberatkan pembangunan dalam bidang ekonomi sehingga kebutuhan kan berbagai bentuk prasarana yang akan mendukung serta menunjang pembangunan di bidang tersebut seperti pembangunan jalan, jembatan, irigasi, bangunan gedung, perumahan, segala sarana dan prasarana berserta infrastrukturnya menjadi sangat diperlukan untuk

${ }^{17}$ R. Subekti, Hukum Perjanjian, (Jakarta: I termasa, 1987), h. 14. berjalannya pembangunan nasional disegala bidang.

Pembangunan di bidang fisik dewasa ini perkembangannya seiring dengan tuntutan masyarakat, kemajuan ilmu pengetahuan dan teknologi. Pembangunan fisik seperti gedung sekolah, jalan tol, rumah sakit, dan lain-lain adalah obyek dari perjanjian bangunan. Perjanjian bangunan dilihat dari sistem hukum merupakan salah satu komponen dari hukum bangungan (bouhwrect), bangunan disini mempunyai arti luas, yaitu segala sesuatu yang didirikan diatas tanah. Dengan demikian dinamakan hukum bangunan adalah seluruh perangkat peraturan perundang-undangan yang berhubungan dengan bangunan meliputi, pendirian, perawatan, pembongkaran, penyerahan baik bersifat perdata maupun publik.

Di Indonesia sendiri proyekproyek bangunan fisik tersebut datang dari pemerintah, swasta domestik maupun asing. Sedangkan pelaksanannya hanya sebagian kecil yang ditangani oleh pemerintah, selebihnya sangat diharapkan peran serta pihak swasta baik sebagai investor maupun kontraktor. Pada dasarnya perjanjian (akad) mempunyai arti penting dalam kehidupan masyarakat. Ia merupakan "dasar kesekian banyak aktivitas keseharian kita". Kenyataan ini menunjukan bahwa betapa kehidupan tidak terlepas dari apa yang namanya perjanjian (akad), yang mengfasilitasi kita dalam memenuhi berbagai kepentingan. 
Setiap peradaban manusia yang perna muncul pasti memberikan perhatian dan pengaturan terhadapnya. Demikian dengan agama Islam, yang memberikan sejumlah prinsip dan dasar-dasar mengenai pengaturan perjanjian sebagaimana tertuang dalan al-Qur'an dan Sunnah Nabi saw.

Dikutib dalam bukunya Syamsul Anwar asas janji itu mengikat, dalam Al-Qur'an dan hadist terdapat perintah agar penuhi janji dan dalam usus figh "pada dasarnya perintah itu wajib". ${ }^{18}$ Hal ini berarti janji itu mengikat dan wajib dipenuhi di antaranya ayat dan hadist dimaksudkan adalah, Firman Allah swt,

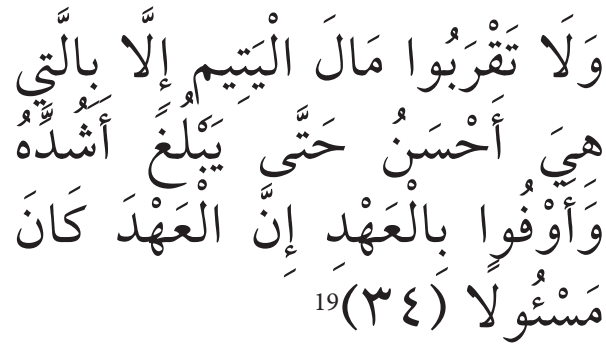

Artinya: Dan penuhilah janji, dan sesunggu janji itu akan diminta pertanggungjawaban". ${ }^{20}$

Di Indonesia sendiri menganut beberapa hukum, baik hukum adat, hukum positif dan hukum Islam. Mengenai perjanjian pemborongan pekerjaan tergantung kesepakatan kedua bela pihak yang mana menjadi hak salah satu pihak dan kewajiban pihak lain. Salah satu perkembangan yang cukup pesat dalam dunia

\footnotetext{
${ }^{18}$ Syamsul Anwar, Hukum Perjanjian Sy riah, (jakarta:Rajawali Pers,2010), h. 89.

${ }^{19}$ QS. Al- Israa' (17): 34

${ }^{20}$ Yayasan Penyelenggara Penerjemahan AlQur'an, (Bandung: Sinar Baru Algesindo, 2006), h. 228
}

modern ini yaitu terlihat pada aspek perjanjian, dimana perjanjian atau verbintenis mengandung makna suatu hubungan hukum kekayaan/harta benda antara dua orang atau lebih, yang memberi kekuatan hak pada pihak untuk memperoleh prestasi dan sekaligus mewajibkan pihak lain untuk memenuhi prestasinya. ${ }^{21}$

Dengan meningkatnya pembangunan fisik seperti: gedunggedung yang bertingkat untuk perumahan, perhotelan, perkantoran, pabrik-pabrik dan perusahan, sarana perhubungan pengairan dan sarana produksi, semuanya memerluhkan pengaturan yang mantap, mengenai segi yuridis dan segi tekhnisnya bangunan yang perluh dikembangkan dan tingkat pelaksanaannya.

Kecendrungan akan terus meningkat jumlah perusahaan, pemborongan, serta meningkatkan penggunaan alat-alat modern dan lain-lain akan banyak menyulitkan permasalahan yang akan datang jika tidak diimbangi dengan peningkatan pengaturannya maupun peningkatan kemampuan dalam pelaksanaannya. ${ }^{22}$ Pasal 1601 Kitab Undang-Undang Hukum Perdata (KUHP) menyatakan bahwa, perjanjian pemborongan termasuk juga dalam perjanjian untuk melakukan pekerjaan yang di dalam hukum Perdata Islam dikenal dengan istilah perjanjian sewa menyewa tenaga manusia (Ijarah al-a'mal) untuk merupakan suatu pekerjaan. Sesuai

${ }^{21}$ M Yahya Harapha, Segi-Segi Hukum Perja jian, Cet. Ke-2 (Bandung: Alumni,1986), h. 6.

${ }^{22}$ Ibid, h. 2. 
dengan firman Allah dalam Al-Qur'an berbunyi:

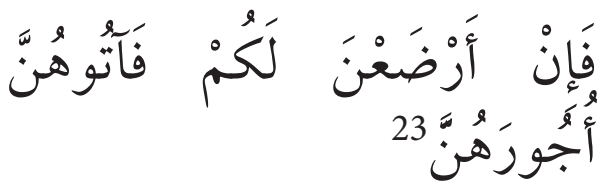

Artinya: jika wanita-wanita itu menyusui anakmu maka berilah upah. ${ }^{24}$

Pada perjanjian pemborongan bangunan memperhatikan berlakunya ketentuan-ketentuan perjanjian untuk melakukan pekerjaan, khususnya bagi bangunan yang diatur dalam Kitab Undang-Undang Hukum Perdata (KUHP) dan berlaku sebagai hukum pelengkap. Peraturan tersebut pada umumnya mengatur tentang hak-hak dan kewajiban pemborong yang harus diperhatikan baik pada pembuatan perjanjian, pelaksanan perjanjian dan berakhir perjanjian. Yaitu fase setelah adanya pelulusan sampai adanya penyerahan pekerjaan.

Pelaksanaan suatu pekerjaan kemungkinan timbul terjadinya wanprestasi yang dilakukan oleh para pihak dalam perjanjian. Luas kemungkinan terjadinya wanprestasi yang dialami oleh salah satu pihak dalam perjanjian pemborongan sehingga pihak tersebut tidak memenuhi prestasinya disebabkan suatu keadaan yang tidak dapat diduga sebelumnya (overmacht). ${ }^{25}$

\footnotetext{
${ }^{23}$ QS. At-Thalaq (65) : 6.

${ }^{24}$ Yayasan Penyelenggara Penerjemahan AlQur'an, (Bandung: Sinar Baru Algesindo, 2006), h. 446

${ }^{25}$ 9Sri Soedewi Masjchoen Sofwan, Hukum Bangunan Perjanjian Pemborongan Bangunan, (Yogyakarta: Liberti, 1982), h. 1.
}

Menurut pasal 48 Kitab UndangUndang Hukum Pidana (KUHP), "Barang siapa yang melakukan perbuatan karena daya paksa, tidak di pidana." ${ }^{26}$ Overmacht menjadi dasar peniadaan hukuman. Hukum perdata pasal 1245 menjelaskan " tidaklah biaya ganti rugi dan bunga, harus digantinya, apabila lantaran keadaan memaksa atau lantaran suatu kejadian tak sengaja. ${ }^{27}$

Dalam Islam istilah overmacht dikenal dengan istilah al-darurat dan ikrah yang berarti merusak atau memberi mudarat, keadaan sangat merusak atau sangat memaksa, kebutuhan yang amat mendesak dan amat berbahaya apabila tidak terpenuhi. ${ }^{28}$ Keadaan memaksa ini misalnya gangguan yang menggunakan kewajiban pertanggungjawaban hukum. Seperti alasan hukum yang membebaskan seseorang dari kewajiban hukum, anak di bawah umur, sakit ingatan, paksaan kelalaian dan ketidaktahuan. Termasuk juga dalam keadaan tersebut adalah memindahkan karena kesukaran dan penderitaan misalnya orang yang berhutang ternyata dalam keadaan sempat untuk membayar hutangnya juga boleh menunda dari waktu yang disanggupkan sampai keadaan leluasa. ${ }^{29}$

\footnotetext{
${ }^{26}$ Andi Hamza, KUHP dan KUHAP, Cet. Ke10 (Jakarta: PT Rineka cipta, 2003), h. 25.

${ }^{27}$ Team Prospect, Kitab Undang-Undang $H$ kum Perdata, Cet. Ke-I (Gama Press, 2010), h. 251.

${ }^{28}$ Abdul Azis Hoeve, Ensiklopedi Hukum I lam, (Jakarta: PT Icthiar Baru Van Hoeve, 2001), h. 260.

${ }^{29}$ Sohbi Mahmasani, Filsafat Hukum dalam Islam, Alih bahasa Ahmad Sudjono (Bandung: PT
} 
Desa Punti Kecamatan Soromandimerupakan bagian wilayah Kabupaten Bima. Rata-rata penduduk desa Punti bermata pencaharian bertani, wilayah desa Punti termasuk wilayah kekeringan yang membutuhkan wadah penampung air agar di musim kemarau bisa bercocok tanam, dengan adanya pembangungan irigasi sebagai wadah penampungan air dan memudahkan petani di desa Punti menunjang perekonomian yang lebih baik. ${ }^{30}$

\section{Desa Punti Kecamatan} Soromandi Kabupaten Bima untuk proyek pembuatan irigasi Tahun 2010 untuk sawah mpungga, dan proyek pembuatan irigasi Tahun 2013 untuk sawah sarita semua dana diperoleh dari pemerintah daerah, hal ini menunjukan bahwa ada pihak yang mengerjakannya dan pihak pemberi pekerjaan maka terjadi perjanjian pekerjaan yang dilakukan oleh kedua pihak yang melahirkan hubungan hukum. ${ }^{31}$

Proyek pembuatan irigasi untuk Tahun 2013 untuk sawah sarita pemegang dananya pemerintah desa, pemeritahdesasebagaipemberipekerja dan masyarakat yang mempunyai sawah sebagai penerima pekerjaan tetapi hanya pada permulaan/awal dibangunnya irigasi selanjutnya pemberi tugas (pemerintah desa) memberikan pekerjaan kepada ahli/ tukangnya dalam bentuk borongan. ${ }^{32}$

al-maarif, 1975), h. 200.

${ }^{30}$ Observasi awal Peneliti

${ }^{31}$ Observasi awal Peneliti

${ }^{32}$ Observasi awal Peneliti
Overmacht/Force majeure dalam hukum perdata positif diatur dalam KUH Perdata pasal 1244 dan 1245, dalam bagian mengenai ganti rugi karena overmacht/force majeure merupakan alasan untuk dibebaskan dari kewajiban membayar ganti rugi.

$\begin{array}{ccc}\text { "Pasal } & 1244 \text { Kitab } & \text { Undang- } \\ \text { Undang } & \text { Hukum } & \text { Perdata }\end{array}$
(KUHPerdata) mengatur. "jika ada alasan si berutang harus dihukum mengganti biaya, rugi, dan bunga, bila ia tidak membuktikan, bahwa hal tidak terlaksanakan atau tidak pada waktu yang tepat dilaksanakannya perjanjian itu disebabkan karena suatu hal yang tak terduga, pun tak dapat dipertanggungjawabkan padanya, kesemuanya itu pun jika itikad buruk tidak ada pada pihaknya". Sementara itu, pasal 1245 Kitab Undang-Undang Hukum Perdata (KUHP) menentukan: "Tidaklah biaya, rugi, dan bunga harus digantinya, apabila karena keadaan memaksa atau karena suatu keadaan yang tidak sengaja, si berutang berhalangan memberikanatauberbuat sesuatu yang diwajibkan, atau karena hal-hal yang sama telah melakukkan perbuatan yang terlarang”.

Berbeda halnya yang terjadi di desa Punti Kecamatan Soromandi kabupaten Bima dalam melakukan kegiatan pemborongan pembuatan irigasi, pihak pemberi borongan ketika terjadiovermachtyangsudahdibuktikan oleh penerima borongan, pemberi borongan meminta dana sumbangsih dari masyarakat yang memiliki sawah di sekitar tempat pembangunan 
irigasi. ${ }^{33}$ Dalam pelaksanaan perjanjian pihak pemberi pekerjaan dengan pihak penerima pekerjaan selama ini berlangsung secara baik, walaupun pada kenyataan terjadi beberapa perbedaan kepentingan di lapangan yang terkait dengan tanggung jawab para pihak. Permasalahan yang sering timbul menyangkut batas waktu dan kekurangan bahan dalam penyelesaian kontrak dimana pihak pemborong belum dapat menyelesaikan pekerjaan yang dilaksanakan. Selain itu permasalahan juga timbul dari pemberi pekerjaan pemborongan bangunan pembuatan irigasi penyangkut penyelesaian pembayaran terjadwal sebagaimana diperjanjikan.

Hal ini terjadi karena pihak pemborong/penerima pekerjaan dengan pihak pemberi pekerjaan didasarirasasalingpercayakarenasudah ada hubungan yang terjalin dengan baik. perbedaan-perbedaan tersebut menjadi persoalan yang terjadi antara pihak pemberi borongan dengan pihak penerima borongan pekerjaan yang diperoleh dari pemerintah dan swasta baik perorangan maupun berbadan hukum. Menyadari pentingnya penyelesaian masalah, maka peneliti akan membahas lebih lanjut mengenai pelaksanaan perjanjian pekerjaan pemborongan bangunan irigasi tersebut.

\section{B. METODOLOGI}

Setiap penulisan karyah ilmiah khususnya skripsi, dapat dipastikan

${ }^{33}$ Hasil Wawancara dengan Syamsudin, sekertaris Desa Punti, Kecamatan Soromandi Kabupaten Bima , 28 Januari 2015 selalu memakai suatu metode. Hal ini karena metode merupakan salah satu instrumen yang penting dalam bertindak, agar suatu penelitian terlaksana dengan terarah sehingga tercapailah hasil yang maksimal. Metode penelitian terdiri dari dua kata yaitu metode dan penelitian. Metode diartikan sebagai suatu cara atau teknis yang dilakukan dalam proses penelitian. Sedangkan penelitian diartikan sebagai upaya dalam bidang ilmu pengetahuan yang dijalankan untuk memperoleh fakta-fakta dan prinsip-prinsip dengan sabar, hati-hati, dan sistematis dalam mewujudkan kebenaran. ${ }^{34}$

\section{Pendekatan Penelitian}

Pendekatan penelitian ini merupakan penelitian studi kasus yang dilakukan secara intensif dan mendalam terhadap para pihak pemborangan pembuatan irigasi, metode pendekatan yang digunakan dalam penelitian ini adalah Metode pendekatan secara yuridis empiris yaitu suatu metode yang memberikan kerangka pembuktian atau kerangka pengujian untuk memastikan suatu kebenaran. ${ }^{35}$

Metode pendekatan tersebut dipergunakan dalam penelitian mengenai kajian yuridis atas perjanjian pemborongan pembuatan irigasi di Desa Punti Kecamatan

${ }^{34}$ Mardalis, Metode Penelitian Suatu Pendek tan Proposal, (jakarta: PT. Bumi Akasara, 2004), h. 24.

${ }^{35}$ Ronny Hanitijo Soemitro, Metode Penel tian Hukum dan Jurimetri, (jakarta: Ghalia Indonesia, 1990), h. 34 
Soromandi Kabupaten Bima. Karena permasalahan yang diangkat dalam penelitian ini membutuhkan data primer dan data sekunder yang kemudiandianalisisuntukmemenukan jawaban dari permasalahan yang muncul dalam penelitian ini.

Pada penelitian ini yang diteliti pada awalnya adalah sekunder kemudian dilanjutkan dengan penelitian terhadap data primer dilapangan, artinya pendekatan ini melakukan penjelasan atas permasalahanyangditelitibersertahasil penelitian diperoleh dalam hubungan dan aspek-aspek hukumnya.

\section{Sumber dan Jenis Data}

Adapun sumber data yang peneliti pakai adalah:

a. Sumber data primer yaitu data peneliti dapatkan langsung dari sumber yang melakukan pemboronganpembuatanirigasi, dan masyarakat sekitar. ${ }^{36}$

b. Sumber data sekunder yaitu data peneliti dapatkan dari bukubuku dan literatur-literatur yang terkait dengan fokus penelitian. Sedangkan jenis penelitian yang digunakanpenelitiialahkualitatif yang berjenis penelitian lapangan (field Recearht) yang berangkat dari studi kasus.

\section{Teknik Pengumpulan Data}

Data yang dikumpulkan meliputi data primer dan data sekunder.

${ }^{36}$ Suharsimis Aritkunto, Prosedur penelitian Suatu Pendekatan Praktik, Cet, V (Jakara; Nasional Legal Reform Program, 2001), h. 172. a. Data primer adalah data yang diperoleh langsung dari masyarakat melalui observasi atau pengamatan, wawancara, interview / wawancara, questionare / angket. ${ }^{37}$ Sedangkan data primer dalam penelitian ini digunakan wawancara secara bebas terpimpin. Wawancara ditentukan terhadap beberapa orang yang telah ditentukan menjadi sampel dalam penelitian ini 5 (Lima) orang dari penerima pekerjaan, 3 (Tiga) orang dari Pemberi pekerjaan (pemerintah desa) dan 2 (Dua) dari masyarakat setempat. Dimana pertanyaan-pertanyaan yang akan diajukan telah dipersiapkan sebelumnya sebagai pedoman penerima informasi, akan tetapi dimungkinkan juga timbul pertanyaan lain yang disesuaikan dengan situasi dan kondisi saat berlangsungnya wawancara.

b. Data sekunder adalah data yang diperoleh melalui kepustakaan dengan menelaah buku-buku, literatur, undangundang, brosur/tulisan yang ada kaitannya dengan yang diteliti. $^{38}$ Dalam penelitian ini ada hubungannya dengan tanggung jawab para pihak dalam perjanjian pemborongan pembuatan irigasi didesa punti kabupaten Bima.

${ }^{37}$ Ronny Hanitijo soemitro, Penelitian Hukum Normatif Suatu Tinjauan Singkat Hukum, (Jakarta: Rajawali, 1985), h. 44.

${ }^{38}$ Loc.cit. 


\section{Teknik Analisis Data}

Teknik analisis data guna memperolehdatayanglengkap,peneliti menggunakan jenis analisis induktif, analisis induktif yaitu menganalisi data dengan mengumpulkan data yang bersifat khusus untuk mendapatkan kesimpulan yang bersifat umum. Dalam hal ini peneliti melakukan analisis terhadap overmacht dalam perjanjian pemborongan pembuatan irigasi di desa Punti kecamatan Soromandi kabupaten Bima. ${ }^{39}$

Semua data yang terkumpul yang diperoleh baik dari data primer dan data sekunder serta semua informasi yang didapatkan akan dianalisis secara kualitatif analisis, artinya: analisis dilakukan dengan menggunakan tahapan analisis kualitatif, data yang diperoleh kemudian disusun secara sistematis, kemudian dianalisis secara kualitatif untuk mencapai kejelasan masalah yang dibahas.

\section{Validitas data}

Validitas data merupakan derajad kecepatan antara data yang terjadi pada objek penelitain dengan data yang dapat dilaporkan oleh peneliti. Dengan demikian data yang valid adalah data-data yang tidak berbeda antara yang dilaporkan oleh peneliti. ${ }^{40}$ Untuk dapat data yang valid peneliti menggunakan beberapa cara yang dilakukan yaitu:

a. Triangulasi

Triangulasi disini dapat diartikan sebagai pengecekan

${ }^{39}$ Lexy j. Moleong, Metode pen elitian Kual tatif, (Bandung: PT Remaja Rosdakarya,, 2001), h. 280.

${ }^{40}$ Sugiyono, Metode Penelitian, (Jakarta: PT Rineka cipta, 2004), h. 267. data dari beberbagai sumber. Jadi triangulasi dilakukan untuk mencari, untuk mengecek data dari sumber tentang apa yang terjadi dilapangan. Triangulasi juga adalah untuk membandingkan dan mengecek balik derajat kepercayaan suatu informasi. Hal tersebut dapat dilakukan dengan cara membandingkan hasil wawancara dengan hasil dokumentasi serta membicarakan dengan teman sejawat.

b. Review adalah mengulang kembali data yang diteliti.

c. Kecukupan referensi. ${ }^{41}$

\section{HASIL DAN PEMBAHASAN}

1. Analisis Terhadap Overmacht Mengenai Prosedur Pelaksanaan Perjanjian Pemborongan Pembuatan Irigasi di Desa Punti Kecamatan Soromandi Kabupaten Bima.

Sebagaimana telah dijelaskan dikajianpustakabahwaovermachtialah keadaan dimana tidak terlaksananya apa yang diperjanjikan karena hal-hal yang sama sekali tidak dapat diduga, dan debitur tidak dapat berbuat apaapa terhadap keadaan atau peristiwa yang timbul di luar dugaan tersebut.

Prosedur pelaksanaan perjanjian pemborongan pembuatan irigasi dilakukan secara lisan antara pemberi borongan dan penerima borongan, terjadinya overmacht dalam pelaksanaan perjanjian pembuatan irigasi di desa Punti Kecamatan Soromandi kabupaten bima yaitu

${ }^{41}$ Sugiono, Metode Penelitian, (Jakarta: PT Rineka cipta, 2004), h. 267-268 
terjadinya bencana alam (Banjir) menyebapkan bangunan irigasi menjadi roboh, pihak penerima borongan yang belum seutuhnya menyelesaikan pekerjaan tidak dapat bertanggung jawab atas kejadian yang menimpah pekerjaannya, pihak penerima borongan dan pemberi borongan sebelum melaksanakan perjanjian, antarakedua pihakinisudah mengikat isi perjanjian yang salah satu dari pada isi perjanjian "apabila terjadi keadaan yang diluar dugaan seperti bencana alam tidak menjadi tanggung jawab pihak penerima borongan".

Walaupun demikian, jika ada yang tidak diinginkan atau masalah dalam pekerjaan pembuat irigasi bukan menjadi persoalan bagi pihak pemberi dan penerima borongan, persoalan-persoalan yang demikian dapat dimusyawarakan, antaranya kekurangan bahan dari pemberi borongan sehingga menyebapkan pengunduran waktu pekerjaan dan tidak dapat diselesaikan sesuai dengan perjanjian awal. Persoalan yang terjadi ketika berlangsungnya pembangunan irigasi yaitu persoalan kekurangan bahan dari pemberi borongan dan bencana alam yaitu banjir yang merobohkan bangunan irigasi. Selain itu, hambatan dalam pembangunan irigasi di desa punti Kecamatan Soromandi Kabupaten Bima yaitu sekolompok masyarakat yang menolak atau tidak setujuh mengenai dana yang dikumpulkan oleh Juraidin M. Tayeb selaku kepala desa Punti untuk pembelian bahan- bahan pengganti bangunan irigasi yang roboh.

Menjadi persoalan bagi kepala Desa Punti bahwa penolakan masyarakat berujung pada keanarkis, bagi pihak penerima borongan tidak dapat menyeelesaikan pekerjaannya sekelompok masyarakat yang tidak setujuh dengan adanya pengumpulan dana tersebut mengecamnya. Persoalan itu terjadi dua hari saja dan dapat diatasi oleh kelapa Desa Punti berserta toko masyarakat. ${ }^{42}$

Persoalan yang terjadi di lapangan antara pemberi dan penerima borongan pembuatan irigasi baik mengenai perselisihan dalam pelaksanaan perjanjian pemborongan tidak dilibatkan kerana hukum, permasalahan terjadi diselesai secara musyawarah, bila ada penuntutan dari pihak luar (masyarakat desa Punti), penyelesaian persoalan diselesaikan oleh pemerintah desa. ${ }^{43}$

Bentuk dan tanggung jawab pemberi dan penerima borongan ketika terjadi overmacht: ${ }^{44}$

a. Pihak pemberi borongan pekerjaan apabila terjadi overmacht berhak menerima laporan secara lisan dari penerima borongan sebaliknya;

b. Pihak pemberi borongan berkewijaban untuk merespon laporan dari penerima

\footnotetext{
${ }^{42}$ Hasil Wawancara dengan MaDfud, Masyarakat Desa Punti, 4 April 2015

${ }^{43}$ Hasil Wawancara dengan Juraidin M. Tayeb, Kepala Desa Punti Kecamatan Soromandi Kabupaten Bima, 2 April, 2015.

${ }^{44}$ Hasil Wawancara Pemberi dan Penerima Borongan, 2 April 2015.
} 
borongan secepatnya sesuai dengan ketentuan isi sesuai isi perjanjian.

c. Pihakpenerimaboronganberhak menerima tambahan waktu untuk menyelesaikan pekerjaan apabila terjadi overmacht.

Overmacht dalam perjanjian pemborongan pembuatan irigasi di desa Punti kecamatan Soromandi kabupaten Bima bukan menjadi tanggung jawab pemerima borongan, penerima borongan dibolehkan melakukan sesuatu terhadap kerusakan bangunan irigasi dengan menerima ganti rugi dari pemberi pekerja.

Hasil wawancara yang dilakukan oleh peneliti menunjukan bahwa pelaksanaan perjanjian pemborongan pembuatan irigasi bermula pada masyarakat yang mempunyai sawah (sawah Sarita), sebagai penerima boronganatasperintahdaripemerintah desa Punti yang sekaligus sebagai pemberi borongan serta mengadakan akad (perjanjian). Perjanjian dilakukan secara lisan. ${ }^{45}$

Menurut peneliti overmacht dalam prosedur pelaksanaan perjanjian pemborongan pembuatan irigasi di desa Punti kecamatan Soromandi kabupaten Bima telah dilaksanakan sesuai dengan ketentuan undang-undang pasal 1338 Kitab Undang-Undang Hukum Perdata yang menyatakan suatu perjanjian tidak dapat ditarik kembali selain dengan

${ }^{45}$ Hasil Wawancara dengan Juraidin M. Tayeb, Kepala Desa Punti Kecamatan Soromandi Kabupaten Bima, 2 April 2015. kesepakatan kedua belak pihak, atau karena alasan yang oleh undangundang dinyatakan cukup untuk itu.

\section{Perspektif Hukum Islam dalam Perjanjian Pemborongan Pembuatan Irigasi di Desa Punti Kecamatan Soromandi Kabupaten Bima.}

Pada dasarnya overmacht atau keadaan memaksa dalam hukum perdata positif dan hukum perdata Islam mempunyai pengertian yang sama hanya saja Islam mempunyai batasan-batasan keadaan memaksa yang mana harus dibebankan kepada debitur misalkan overmacht menurut batasan hukum perdata Islam ialah suatu paksaan apabila suatu ancaman yang cukup mempengaruhi orang yang berakal dan berpikiran sehat mengerjakan apa yang dipaksakan kepadanya serta timbul dugaan kuat pada dirinya bahwa ancaman tersebut akan dikenakan pada dirinya apabila ia menolak apa yang dipaksakan. ${ }^{46}$

Sedangkan overmacht dalam hukum perdata positif khususnya dalam hukum pidana hanya terbatas pada hal-hal paksaan psikis yang biarpun masih bisa dilawan tetapi dari orang dipaksa tidak dapat melakukan perlawanan dalam hukum perdata hanya terbatas pada overmacht absolut yaitu suatu keadaan diakibatkan bencana alam atau keadaan disangka sebelumnya. Dalam keadaan seperti

${ }^{46}$ Hardianto Siagian, Overmacht Menurut Hukum Positif dan Hukum Islam, Skripsi Fakultas Syariah IAIN Sunan Kali Jaga Yogyakarta, 2010, tidak diterbitkan. Dalam http://digilib. Uin-suka. as.id./4983/, diakses tanggal 18 Febrari 2015. 
ini seseorang yang kedudukan sebagai debitur tidak dikenakan beban ganti rugi.

Perspektif hukum Islam terhadap overmacht dalam perjanjian pemborongan pembuatan irigasi di desa Punti kecamatan Soromandi kabupaten Bima bahwa perspektif hukum Islam dalam perjanjian pemborongan memberikan peluang kepada pihak yang lemah menyatakan bahwa dirinya tidak bersalah dan tidak menanggung sesuatu yang diluar perkiraannya dan menyuruh manusia untuk menjaga lima ekstensi yaitu agama, jiwa, akal, kehormatan/keturunan dan harta yang dibutuhkannya dan hal tersebut tidak memandang dosa. ${ }^{47}$

Overmacht dalam perjanjian pemborongan pembuatan irigasi di desa Punti, pihak pemberi dan penerima borongan mengadakan musyawarah untuk mencapai kesepakatan. Islam juga memandang musyawarah sebagai salah satu yang amat penting bagi kehidupan insani bukan saja dalam kehidupan berbangsa dan bernegara melainkan dan dalam kehidupan berumah tangga termasuk dalam hal perikatan dan lain-lainnya.

Al-Qur'an yang memerintahkan atau menganjurkan umat pemeluknya supaya bermusyawarah dalam memecahkan berbagai persoalan yang mereka hadapai. Dalam surah AlImran ayat 159 sesuai dengan firman Allah swt yang berbunyi:

${ }^{47}$ Abdul Azis Dahlan, Ensiklopedi..., h.260

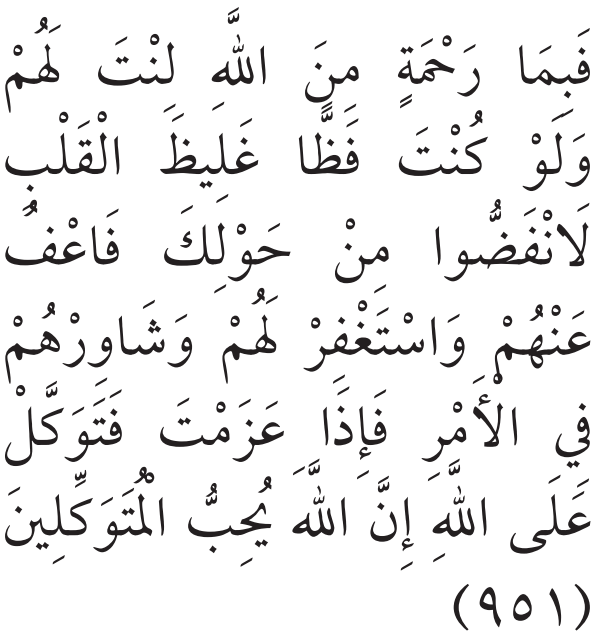

Artinya: "Maka berkat rahmat Allah engkau (Muhammad) berlaku lemah lembut terhadap mereka. Sekiranya engkau bersikap keras dan berhati kasar, tentu mereka menjauhkan dari sekitar mu. Karena itu maafkanlah mereka dan memohon ampunan untuk mereka, dan bermusyawarahlah dengan mereka dalam urusan mereka itu.160 kemudian, apabila engkau telah membulatkan tekad maka sesunggunya bertawakalah kepada Allah". Sungguh Allah mencintai orang yang bertawakal". ${ }^{48}$

Menurut Ibnu Hujaim (w. $970 \mathrm{H} / 1563 \mathrm{M}$ ), ahli fikih Mazhab Hanafi, sebagaimana yang dikutif dalam bukunya Abdul Azis Dahlan, menyatakan bahwa ad-darurah berarti sampainya seseorang pada suatu batas, yang apabila melakukan sesuatu yang dilarang akan mencelakan dirinya. Fukaha Mazhab Malikimendefinisikan darurat sebagai sesuatu kekhawatiran atas kebinasaan diri, baik berdasarkan keyakinan maupun berdasarkan dugaan yang kuat. Ad-darurah (darurat) ini tidak terujud kecuali ada suatu keadaan yang memaksa

${ }^{48}$ Yayasan Penyelenggara Penerjemahan AlQur'an, (Bandung: Sinar Baru Algesindo, 2006), h. 56. 
untuk melakukan yang diharamkan agar terpelihara diri dari kebinasaan, seperti haus dan lapar yang berlebihan atau sakit yang membawa kematian, Yusuf Qasim, ulama kontemporer Mesir, berpendapat bahwa kebinasaan itu tidak hanya terhadap diri atau jiwa seseorang tetapi juga terhadapat harta. ${ }^{49}$

Apabila dalam perjanjian pemborongan terjadi keadaan memaksa (overmacht) dan dapat dibuktikan oleh debitur, hukum positif mengaturnya dalam peraturan perundang-undangan mengenai peraturan pengadaan barang dan jasa antara lain: peperangan, kerusuhan, revolusi, bencana alam, wabah penyakit, pemogokan, kebakaran dan gangguan insdustri lainnya, kenaikan harga. ${ }^{50}$

Overmacht yang diatur dalam kontrak misalnya mengenai pemborongan (kontrak) Pekerjaan Rencana terakhir (FED), antara lain: gempa bumi, tanah longsor, banjir, guntur, kebakaran, perang, hura-hara, pemogokan, pemberontakan, dan epidemis (wabah yang lebih cepat dari pada yang diduga). ${ }^{51}$

a. Overmacht dalam hukum perdata Islam

1) Dilihat dari segi dasar hukum

\footnotetext{
${ }^{49}$ bid.,

${ }^{50}$ Soemadipradja Rahmat S,S, Penjelasan H kum..., h.77. dan lihat juga diPerpres No.70 Tahun 2012 tentang Perubahan kedua Atas peraturan Presiden Nomor 54 Tahun 2010 tentang Pengadaan Barang/ Jasa Pemerintah, Pasal 38, h.35.

${ }^{51}$ Ibid..,
}

Dalam hukum perdata islam dasar hukum dari ad-darurah (overmacht) bersumber dari Al-Qur'an dan sunah. Dalam Al-Qur'an dijelaskan apabila seseorang dalam keadaan yang terpaksa tanpa sengaja dan tidak melampui (QS. $2: 173$, 6: 145, dan 16: 115;). ${ }^{52}$ Sesuai dengan firman Allah swt. Yang berbunyi:

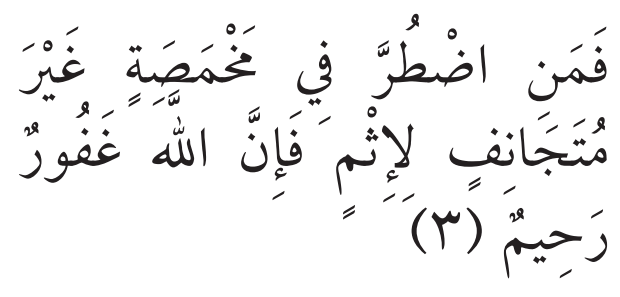

"Maka barang siapa karena terpaksa karena kelaparan tanpa sengaja berbuat dosa, sesungguhnya Allah maha pengampun lagi maha penyayang". ${ }^{53}$

2) Dilihat dari Segi-Segi SyaratSyarat

Ad-darurah dalam hukum perdata Islam memiliki Syarat-Syarat dari kondisi darurat yang dihadapi, yaitu:

a) Bahaya yang dihadapi besar dan

b) Bahaya tersebut sedang berlangsung. ${ }^{54}$

Sedangkan dalamhukumperdata positif tidak mengenal syarat-syarat mengenai force majuere/overmacht. Sedangkan dilihat dari hukumnya bahwa overmacht (Ad-darurat) menurut

\footnotetext{
${ }^{52}$ Lihat QS. Al-Baqarah (2): 173, QS. AlAn'am (6): 145, dan QS. An-Nahl (16): 115 .

${ }^{53}$ Yayasan Penyelenggara Penerjemahan AlQur'an, (Bandung: Sinar Baru Algesindo, 2006), h. 85.

${ }^{54}$ Abdul Azis Dahlan, Ensiklopedi....., h. 261.
} 
Syamsul Anwar, akibat hukum dari putusnya akad karena sebap luar, seperti keadaan memaksa (keadaan darurat karena bencana), atau pihak ketiga yang terkait dengan para pihak dikembalikan kepada keadaan seperti sedia kala yaitu seolah-olah tidak pernah terjadi akad. Bila penjual yang ternyata penjualbarangyangdijual dan belum diserahkannya kepada pembeli musnah itu telah terlanjur menerima harga pembelian dari pembeli, maka ia wajib mengembalikan harga tersebut kepada pembeli. ${ }^{55}$

\section{KESIMPULAN}

Berdasarkan temuan dan pembahasan data dirumuskan beberapa kesimpulan yaitu sebagai berikut:

1. Prosedur pelaksanaan perjanjian pembuatan irigasi dilakukan berdasarkan ketentuan pasal 1338 Kitab Undang-Undang Hukum Perdata menyatakan semua perjanjian dibuat secara sah dan berlaku sebagaimana undang-undang bagi mereka yang membuatnya. Dan dapat dilihat ketika terjadi overmacht tidak menjadi tanggung jawab penerima borongan, pihak penerima borongan boleh melakukan seseuatu terhadap bangunan irigasi yang roboh dan berhak menerima seluruh biaya ganti rugi dari pengguna jasa pemborong(pemberiborongan). Prosedur perjanjiannya dilakukan secara lisan, ketika terjadi overmacht pada saat pekerjaan masih dikerjakan oleh penerima borongan tidak libatkan ke ranah hukum hanya saja antara pihak bermusyawarah untuk mencapai kesepakatan.

2. Overmacht dalam perjanjian pemborongan pembuatan irigasi di Desa Punti kecamatan Soromandi kabupaten Bima, ketika terjadi overmacht maupun wanprestasi Islam mengajarkan beberapa cara dalam penyelesaian itu sebagai berikut: Shulhu(perdamaian), (tahkim)Arbitrase, alqadhal(pengandilan), dalam perjanjian pemborongan irigasi ketika terjadi overmacht mengambil keputusan dalam menyelesaikan persoalan dengan cara bermufakat untuk bermencapai kesepakatan.

\section{DAFTAR PUSTAKA}

Abdul Azis Hoeve, Ensiklopedi Hukum Islam, (Jakarta: PT Icthiar Baru Van Hoeve, 2001)

Hamza, KUHP dan KUHAP, Cet. Ke-10 (Jakarta: PT Rineka cipta, 2003)

Lexy j. Moleong, Metode pen elitian Kualitatif, (Bandung: PT Remaja Rosdakarya,, 2001)

M Yahya Harapha, Segi-Segi Hukum Perjanjian, Cet. Ke-2 (Bandung: Alumni,1986), 
Mardalis, Metode Penelitian Suatu Pendekatan Proposal, (jakarta: PT. Bumi Akasara, 2004)

R. Subekti, Hukum Perjanjian, (Jakarta: Intermasa, 1987)

Ronny Hanitijo Soemitro, Metode Penelitian Hukum dan Jurimetri, (jakarta: Ghalia Indonesia, 1990)

Ronny Hanitijo soemitro, Penelitian Hukum Normatif Suatu Tinjauan Singkat Hukum, (Jakarta: Rajawali, 1985)

Perpres No.70 Tahun 2012 tentang Perubahan kedua Atas peraturan Presiden Nomor 54 Tahun 2010 tentang Pengadaan Barang/Jasa Pemerintah,

Sohbi Mahmasani, Filsafat Hukum dalam Islam, Alih bahasa Ahmad Sudjono (Bandung: PT al-maarif, 1975)
Sri Soedewi Masjchoen Sofwan, Hukum Bangunan Perjanjian Pemborongan Bangunan, (Yogyakarta: Liberti, 1982)

Sugiyono, Metode Penelitian, (Jakarta: PT Rineka cipta, 2004)

Suharsimis Aritkunto, Prosedur penelitian Suatu Pendekatan Praktik, Cet, V (Jakara; Nasional Legal Reform Program, 2001)

Syamsul Anwar, Hukum Perjanjian Syariah, (jakarta:Rajawali Pers,2010)

Team Prospect, Kitab Undang-Undang Hukum Perdata, Cet. Ke-I (Gama Press, 2010)

Yayasan Penyelenggara Penerjemahan Al-Qur'an, (Bandung: Sinar Baru Algesindo, 2006) 